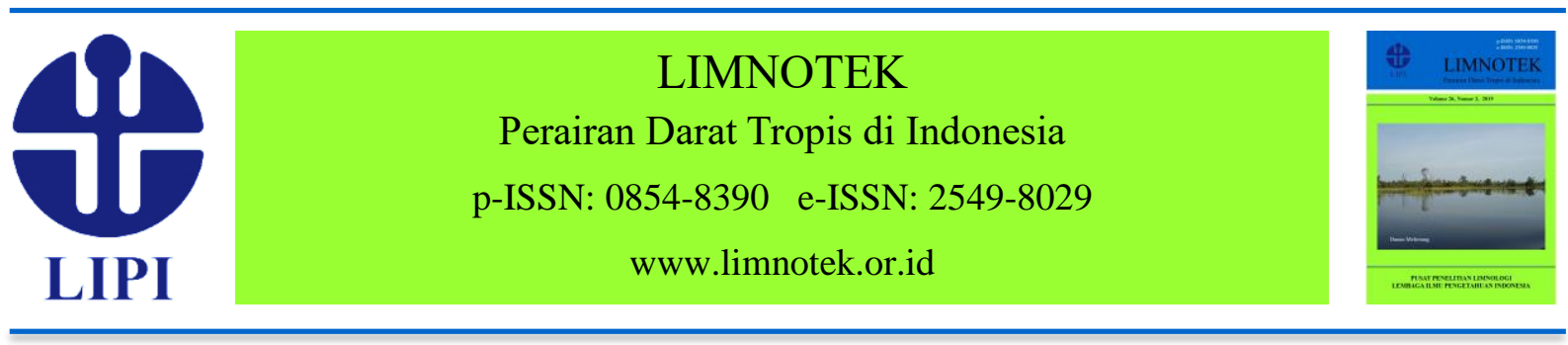

\title{
Keanekaragaman dan Komposisi Keong Air Tawar (Mollusca: Gastropoda) di Beberapa Situ Kabupaten Bogor dan Kabupaten Sukabumi
}

\author{
Nova Mujiono ${ }^{1,2 *}$, Afriansyah ${ }^{1}$, Alexander KS Putera ${ }^{1}$, \\ Tri Atmowidi ${ }^{1}$, Windra Priawandiputra ${ }^{1}$ \\ ${ }^{1}$ Departemen Biologi FMIPA, Institut Pertanian Bogor \\ ${ }^{2}$ Pusat Penelitian Biologi, Lembaga Ilmu Pengetahuan Indonesia \\ *Email : nova.mzb@gmail.com
}

Diajukan 8 Oktober 2018. Ditelaah 29 Mei 2019. Disetujui 6 November 2019.

\begin{abstract}
Abstrak
Banyak situ di daerah Bogor dan sekitarnya terus menyusut oleh pendangkalan maupun alih fungsi lahan yang akan berpengaruh pada keanekaragaman spesies fauna akuatik, termasuk keong air tawar. Penelitian mengenai keanekaragaman dan ditribusi keong air tawar penghuni situ dilakukan di Kabupaten Bogor (Situ Cilalay, Situ Ciriung, Situ Kabantenan) dan di Sukabumi (Situ Gunung) pada bulan September-November 2017. Penelitian ini mengidentifikasi spesies keong air tawar, menganalisis persamaan komposisi spesies dan distribusinya, serta menganalisis faktor lingkungan yang memengaruhinya. Pengambilan sampel keong di masing-masing situ dilakukan di tiga stasiun menggunakan petak berukuran $5 \times 1 \mathrm{~m}^{2}$. Sebanyak 936 individu spesimen dari 12 stasiun telah dikoleksi dan diidentifikasi, terdiri dari 7 famili dan 12 spesies keong air tawar. Filopaludina javanica mendominasi populasi di Situ Cilalay, Situ Ciriung, dan Situ Kabantenan dengan kehadiran 417 individu (44,5\%), sementara Melanoides tuberculata merupakan spesies dengan distribusi paling luas yang ditemukan di 11 dari 12 stasiun. Dua spesies, Clea sp. yang ditemukan di Situ Cilalay dan Polypylis kennardi yang ditemukan di Situ Ciriung dan Situ Kabantenan belum pernah dilaporkan penelitian terdahulu.
\end{abstract}

Kata kunci: situ, keong air tawar, spesies, Kabupaten Bogor, Kabupaten Sukabumi

\begin{abstract}
Diversity and Composition of Freshwater Snails (Mollusca: Gastropoda) in Small Lakes of Bogor and Sukabumi Regencies. Many small lakes in Bogor and surrounding areas continue to shrink by silting and land conversion that will affect the diversity of aquatic fauna species, including freshwater snails. Research on the diversity and distribution of freshwater snails was conducted in Bogor Regency (Situ Cilalay, Situ Ciriung, Situ Kabantenan) and Sukabumi (Situ Gunung) in September-November 2017. This study identified freshwater snail species, analyzed the similarity of species composition and distribution, and analyzed the influencing environmental factors. Snail sampling from each lake was carried out at three stations using $5 \times 1 \mathrm{~m}^{2}$ plots. A total of 936 individual specimens from 12 stations have been collected and identified, consisting of 7 families and 12 species of freshwater snails.
\end{abstract}


Filopaludina javanica dominates the population in Situ Cilalay, Situ Ciriung, and Situ Kabantenan with the presence of 417 individuals (44.5\%), while Melanoides tuberculata is the most widely distributed species found in 11 of 12 stations. The presence of two species, Clea sp. found in Situ Cilalay and Polypylis kennardi found in Situ Ciriung and Situ Kabantenan, has not been reported previously.

Keywords: small lakes, freshwater snail, species, Bogor Regency, Sukabumi Regency

\section{Pendahuluan}

Pada sekitar dua dekade yang lalu terdapat 218 situ di wilayah Jabotabek dengan luas total 2.166 ha. Lokasi situ-situ tersebut menyebar dengan rincian: Jakarta (35), Bogor (122), Tangerang (45), dan Bekasi (16). Namun sayangnya, jumlah dan luas situ-situ tersebut telah jauh berkurang hingga menjadi 164 buah dengan luas total sekitar 1.978 ha (Suryadiputra, 2003). Penyebab penurunan jumlah dan luas situ-situ tersebut diduga karena sedimentasi dan alih fungsi lahan. Sama seperti daerah yang lain, jumlah situ di Bogor juga menyusut dari 122 menjadi 94 (hilang 28 buah), sehingga menurut perkiraan luasnya kini hanya mencapai 613 ha (Suryadiputra, 2003).

Situ merupakan tempat hidup bagi invertebrata akuatik seperti serangga air, keong, kerang, dan cacing (Oktarina \& Syamsudin, 2015). Selain kelompok invertebrata, situ juga menjadi habitat bagi kelompok vertebrata seperti ikan. Namun sayangnya, sebuah studi menunjukkan bahwa komposisi spesies ikan asli di beberapa situ di aliran Sungai Cisadane telah mengalami penurunan sebanyak $72,1 \%$ dibandingkan dengan tahun 1910 (Hadiaty, 2011). Hal yang sama juga terjadi pada keong air tawar. Marwoto \& Isnaningsih (2014) melaporkan ada delapan spesies keong air tawar (tanpa menyebutkan spesiesnya) yang sudah hilang, namun pernah ditemukan di situ-situ DAS Ciliwung-Cisadane pada tahun 1956.

Mengingat jumlah dan luas situ-situ yang ada di Jabotabek yang semakin menyusut dan berdampak langsung terhadap komposisi spesies keong air tawar, maka penelitian untuk mendata ulang atau memonitor keberadaan spesies keong asli perlu dilakukan. Spesies keong asli yaitu spesies keong yang menyebar secara alami tanpa perantaraan manusia atau hewan. Penelitian ini mengidentifikasi berbagai spesies keong air tawar di beberapa situ di Kabupaten Bogor dan Kabupaten Sukabumi, menganalisis persamaan komposisi spesies dan distribusinya, serta menganalisis faktor lingkungan yang memengaruhinya. Hasilnya diharapkan dapat digunakan sebagai data dasar bagi pengelolaan perairan situ pada masa mendatang.

\section{Bahan dan Metode}

Penelitian ini dilakukan di empat situ, tiga situ di Kabupaten Bogor dan satu di Kabupaten Sukabumi sebagai pembanding (Gambar 1). Tiga situ di Bogor terletak di dataran rendah dan dikelilingi oleh permukiman, sedangkan situ di Sukabumi terletak di dataran tinggi dan dikelilingi oleh hutan alami. Penelitian dilakukan dalam rentang waktu bulan September-November 2017. Penentuan status tingkat pencemaran mengacu pada pengamatan visual di perairan saat pengambilan sampel, selain merujuk pada Nugroho (2006) dan Puspita (2017).

Situ-situ tersebut yaitu :

1. Situ Cilalay di Cibinong, Kecamatan Cibinong, Kabupaten Bogor, dengan koordinat: $-6,494141,106,852467$. Luas situ 1,5 ha dengan karakteristik ekosistem buatan yang sudah sangat mendekati alami, perkiraan usia sekitar 20 tahun, dikelilingi oleh kompleks perkantoran, tingkat pencemaran rendah. Titik stasiun pengambilan sampel 1.1-1.3.

2. Situ Ciriung di Ciriung, Kecamatan Cibinong, Kabupaten Bogor, dengan koordinat: -6,469446, 106,857162. Luas situ 9,2 ha dengan karakteristik ekosistem alami dengan modifikasi berupa tembok pembatas di sekelilingnya, dikelilingi oleh kompleks permukiman, tingkat pencemaran tinggi. Titik stasiun pengambilan sampel 2.1-2.3.

3. Situ Kabantenan di Pakansari, Kecamatan Cibinong, Kabupaten Bogor, dengan koordinat: $-6,479334,106,833226$. Luas situ 4,5 ha dengan karakteristik ekosistem alami dengan modifikasi berupa tembok pembatas di sekelilingnya, dikelilingi oleh kompleks 
permukiman, tingkat pencemaran tinggi. Titik stasiun pengambilan sampel 3.1-3.3.

4. Situ Gunung di Gunung Gede Pangrango, Kecamatan Kadudampit, Kabupaten Sukabumi, dengan koordinat: $-6,831947$, 106,923113. Luas situ 6 ha dengan karakteristik ekosistem alami, berada di atas bukit, dikelilingi hutan alami, tingkat pencemaran rendah. Titik stasiun pengambilan sampel 4.1-4.3.

Sebanyak tiga stasiun pengambilan sampel keong dengan luas petak $5 \times 1 \mathrm{~m}^{2}$ ditentukan di setiap situ. Pengambilan keong mikro ( $<10 \mathrm{~mm}$ ) menggunakan ayakan dengan diameter jaring $2 \mathrm{~mm}$, sedangkan untuk keong yang lebih besar menggunakan pinset. Waktu pengambilan sampel masing-masing selama 1 jam. Semua sampel keong hidup atau mati dimasukkan ke dalam plastik ziplock dan direndam alkohol $70 \%$ untuk pengawetan sementara. Kemudian, sampel dibawa ke Laboratorium Moluska Museum Zoologi Bogor untuk diidentifikasi dengan merujuk pada van Bentem-Jutting (1956).

Spesimen difoto menggunakan kamera Canon Powershot A710IS. Namun, beberapa spesies yang berukuran $<10 \mathrm{~mm}$ difoto menggunakan mikroskop Olympus SZX7 dan kamera Olympus $\varepsilon 330$, lempeng gambar spesimen dibuat menggunakan program Adobe Photoshop 7.

Titik koordinat lokasi ditandai dengan GPS eTrex30. Beberapa parameter fisika-kimia air yang diukur antara lain suhu, diukur menggunakan termometer alkohol, $\mathrm{pH}$ air, diukur menggunakan kertas $\mathrm{pH}$ (McolorpHast), $\mathrm{pH}$ substrat lumpur, diukur menggunakan Soil Tester DM-5, oksigen terlarut diukur menggunakan DOmeter Lutron 5509. Masingmasing pengukuran dilakukan selama lima menit untuk mencapai nilai yang konstan. Analisis populasi, CCA antara jumlah spesies dan empat parameter fisika-kimia air, analisis klaster untuk komposisi spesies dan distribusi spesies menggunakan program PAST 2.17c dilakukan berdasarkan Hammer et al. (2001). Penghitungan beberapa indeks beserta kategorinya dalam populasi mengacu pada Magurran (2004), yaitu indeks dominansi Simpson: rendah (kisaran nilai $0,0-0,5$ ), sedang $(0,50-0,75)$, tinggi $(0,75-1,00)$. Indeks keanekaragaman Shannon-Wiener: rendah $(0,0$ $0,3)$, sedang $(0,4-0,6)$, tinggi $(0,7-1,0)$. Indeks kemerataan Pielou: rendah $(<0,4)$, sedang $(0,4-$ $0,6)$, tinggi $(>0,6)$.

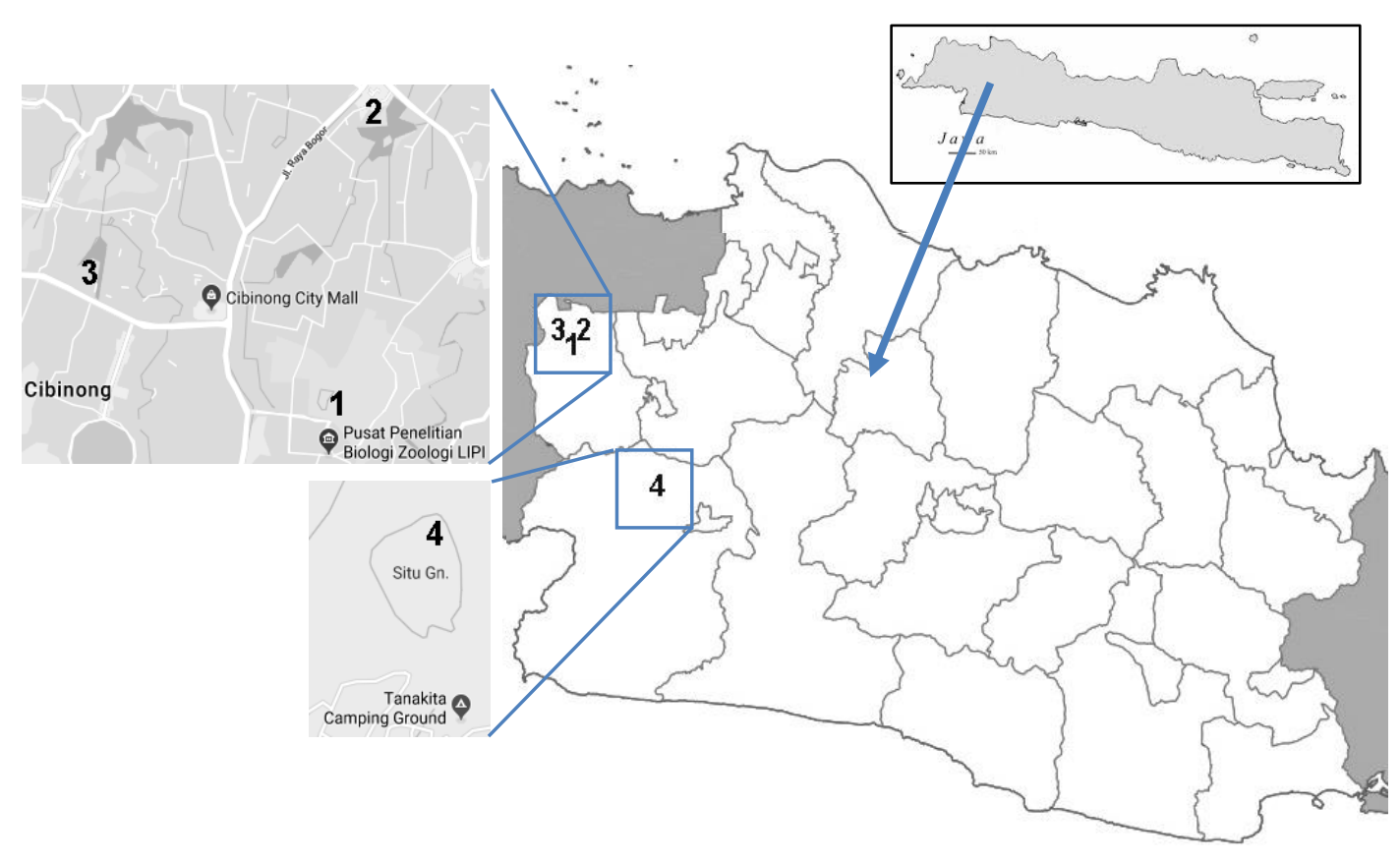

Gambar 1. Peta lokasi pengambilan sampel keong 


\section{Hasil}

Penelitian ini berhasil mengoleksi sebanyak 936 individu keong air tawar dari 12 titik pengambilan sampel $\left(12 \times 5=60 \mathrm{~m}^{2}\right)$. Komposisinya terdiri dari tujuh famili dan 12 spesies keong air tawar (Gambar 2). Jumlah spesies bervariasi mulai dari tiga sampai dengan sembilan spesies per situ.

Jumlah individu/spesies sangat bervariasi, mulai dari Clea sp. yang hanya satu individu dijumpai hingga Filopaludina javanica dengan
420 individu dan Melanoides tuberculata dengan 159 individu. Begitu pun dengan persebarannya, mulai dari Clea sp. yang hanya dijumpai di satu titik hingga Melanoides tuberculata yang dijumpai di 11 titik dan Filopaludina javanica di 10 titik (Tabel. 1). Beberapa spesies keong memiliki distribusi yang sempit sehingga hanya dijumpai di satu situ saja, antara lain Clea sp. (Situ Cilalay), Wattebledia crosseana (Situ Ciriung), Sermyla requeti dan Sulcospira testudinaria (Situ Gunung).

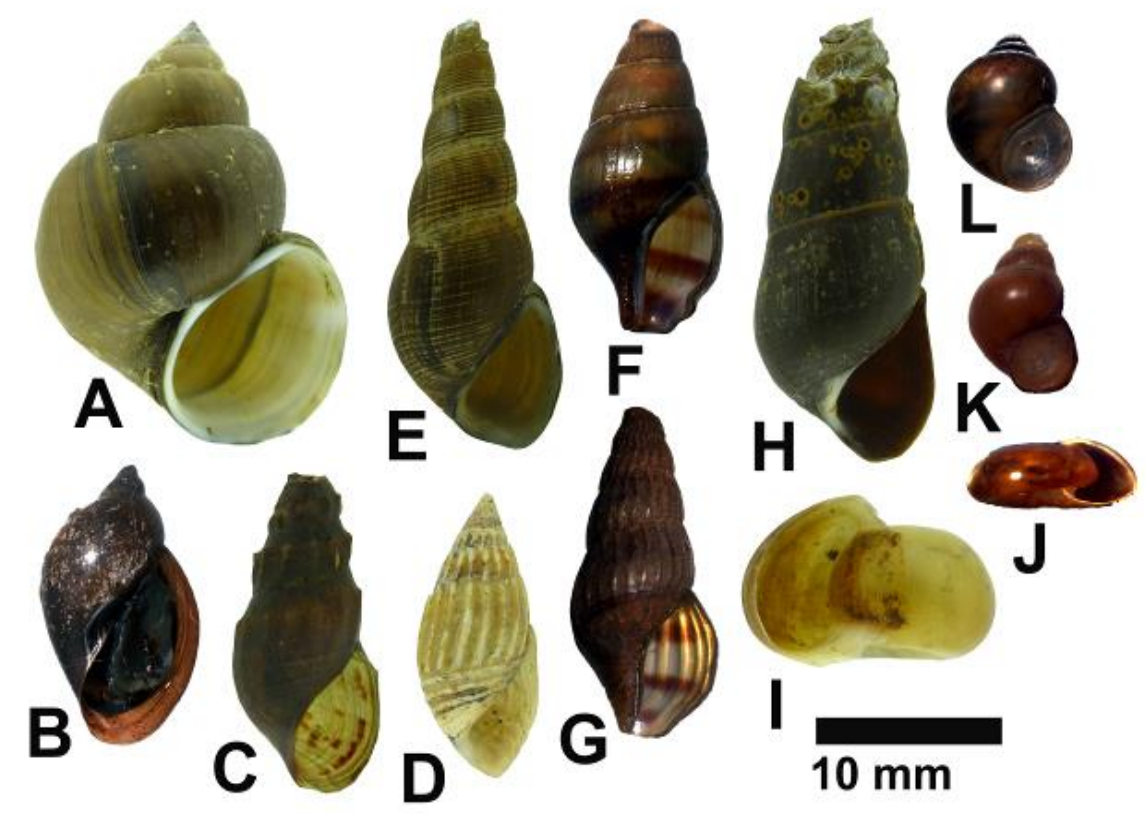

Gambar 2. Morfologi cangkang keong air tawar yang dijumpai dalam penelitian ini. A. Filopaludina javanica, B. Radix rubiginosa, C. Thiara scabra, D. Sermyla riqueti, E. Melanoides tuberculata, F. Clea sp., G. Anentome helena, H. Sulcospira testudinaria, I. Indoplanorbis exustus, J. Polypylis kennardi, K. Wattebledia crosseana, L. Bythinia truncatum 
Tabel 1. Komposisi spesies dan distribusi keong air tawar

\begin{tabular}{|c|c|c|c|c|c|c|c|c|c|c|c|c|c|c|c|}
\hline \multirow{2}{*}{ Famili } & \multirow{2}{*}{ Spesies } & \multicolumn{12}{|c|}{ Stasiun pengambilan sampel } & \multirow{2}{*}{$\begin{array}{c}\text { Jumlah } \\
\text { individu }\end{array}$} & \multirow{2}{*}{$\begin{array}{c}\text { Distribus } \\
\text { lokasi }\end{array}$} \\
\hline & & 1.1 & 1.2 & 1.3 & 2.1 & 2.2 & 2.3 & 3.1 & 3.2 & 3.3 & 4.1 & 4.2 & 4.3 & & \\
\hline Viviparidae & Filopaludina javanica & 63 & 4 & 27 & 50 & 32 & 32 & 89 & 84 & 36 & 3 & 0 & 0 & 420 & 10 \\
\hline Lymnaeidae & Radix rubiginosa & 0 & 0 & 0 & 2 & 12 & 3 & 22 & 6 & 4 & 2 & 0 & 0 & 51 & 7 \\
\hline Thiaridae & Thiara scabra & 0 & 0 & 0 & 10 & 0 & 0 & 2 & 13 & 6 & 0 & 0 & 0 & 31 & 4 \\
\hline Thiaridae & Sermyla riqueti & 0 & 0 & 0 & 0 & 0 & 0 & 0 & 0 & 0 & 0 & 9 & 0 & 9 & 1 \\
\hline Thiaridae & Melanoides tuberculata & 0 & 14 & 27 & 29 & 9 & 18 & 14 & 7 & 21 & 6 & 12 & 2 & 159 & 11 \\
\hline Nassariidae & Clea sp. & 0 & 0 & 1 & 0 & 0 & 0 & 0 & 0 & 0 & 0 & 0 & 0 & 1 & 1 \\
\hline Nassariidae & Anentome helena & 0 & 0 & 0 & 4 & 61 & 1 & 4 & 0 & 0 & 0 & 0 & 0 & 70 & 4 \\
\hline Pachychilidae & Sulcospira testudinaria & 0 & 0 & 0 & 0 & 0 & 0 & 0 & 0 & 0 & 1 & 3 & 1 & 5 & 3 \\
\hline Planorbidae & Indoplanorbis exustus & 0 & 0 & 0 & 4 & 7 & 3 & 5 & 4 & 42 & 0 & 0 & 0 & 65 & 6 \\
\hline Planorbidae & Polypylis kennardi & 0 & 0 & 0 & 0 & 10 & 2 & 22 & 0 & 0 & 0 & 0 & 0 & 34 & 3 \\
\hline Bithyniidae & Wattebledia crosseana & 0 & 0 & 0 & 0 & 6 & 2 & 0 & 0 & 0 & 0 & 0 & 0 & 8 & 2 \\
\hline Bithyniidae & Bithynia truncatum & 0 & 0 & 0 & 4 & 8 & 1 & 50 & 20 & 0 & 0 & 0 & 0 & 83 & 5 \\
\hline
\end{tabular}

Tabel 2. Beberapa nilai indeks dalam populasi keong air tawar

\begin{tabular}{|c|c|c|c|c|c|c|c|c|c|c|c|c|}
\hline \multirow{2}{*}{ Parameter } & \multicolumn{12}{|c|}{ Stasiun pengambilan sampel } \\
\hline & 1.1 & 1.2 & 1.3 & 2.1 & 2.2 & 2.3 & 3.1 & 3.2 & 3.3 & 4.1 & 4.2 & 4.3 \\
\hline Jumlah spesies & 1 & 2 & 3 & 7 & 8 & 8 & 8 & 6 & 5 & 4 & 3 & 2 \\
\hline Jumlah individu & 63 & 18 & 55 & 103 & 145 & 62 & 208 & 134 & 109 & 12 & 24 & 3 \\
\hline Kepadatan $/ \mathrm{m}^{2}$ & 12,6 & 3,6 & 11,0 & 20,6 & 29,0 & 12,4 & 41,6 & 26,8 & 21,8 & 2,4 & 4,8 & 0,6 \\
\hline Indeks dominansi & 1,00 & 0,65 & 0,48 & 0,33 & 0,25 & 0,36 & 0,27 & 0,43 & 0,30 & 0,35 & 0,41 & 0,56 \\
\hline Indeks keanekaragaman & 0,00 & 0,35 & 0,52 & 0,67 & 0,75 & 0,64 & 0,73 & 0,57 & 0,70 & 0,65 & 0,59 & 0,44 \\
\hline Indeks kemerataan & 1,00 & 0,85 & 0,72 & 0,57 & 0,68 & 0,48 & 0,60 & 0,55 & 0,76 & 0,83 & 0,88 & 0,94 \\
\hline
\end{tabular}


Jumlah spesies per stasiun pengambilan sampel bervariasi mulai dari hanya satu spesies (Filopaludina javanica) di Stasiun 1.1 hingga delapan spesies di Stasiun 2.2, 2.3, dan 3.1. Jumlah individu bervariasi mulai dari tiga individu di Stasiun 4.3 hingga 208 individu di Stasiun 3.1. Filopaludina javanica mendominasi populasi di Stasiun 3.1 dengan jumlah 89 individu $(42,7 \%)$. Kepadatan populasi berkisar dari 0,6 individu $/ \mathrm{m}^{2}$ di Stasiun 4.3 hingga 41,6 individu $/ \mathrm{m}^{2}$ di Stasiun 3.1. (Tabel 2).

Indeks dominansi berkisar dari $0,25 \mathrm{di}$ Stasiun 2.2 hingga 1,00 di Stasiun 1.1. Hal ini disebabkan di Stasiun 1.1 hanya ada spesies Filopaludina javanica saja, sedangkan di Stasiun 2.2 ditemukan delapan spesies.

Indeks keanekaragaman berkisar dari 0,00 di Stasiun 1.1 hingga 0,75 di Stasiun 2.2. Hal ini disebabkan di Stasiun 1.1 hanya ada spesies Filopaludina javanica saja, sedangkan di Stasiun 2.2 ditemukan delapan spesies.

Indeks kemerataan berkisar dari $0,48 \mathrm{di}$ Stasiun 2.3 hingga 1,00 di Stasiun 1.1. Hal ini disebabkan di Stasiun 1.1 hanya ada spesies Filopaludina javanica, sedangkan di Stasiun 2.3 ditemukan delapan spesies.

Tabel 3. Posisi dan ketinggian setiap lokasi beserta paramater fisika-kimia perairan

\begin{tabular}{|c|c|c|c|c|c|c|c|}
\hline & Lintang & Bujur & $\begin{array}{l}\text { Tinggi } \\
(\mathrm{mdpl})\end{array}$ & $\begin{array}{c}\text { Suhu } \\
\left({ }^{\circ} \mathrm{C}\right)\end{array}$ & $\begin{array}{l}\mathrm{pH} \\
\text { air }\end{array}$ & $\begin{array}{c}\mathrm{pH} \\
\text { substrat }\end{array}$ & $\begin{array}{c}\text { Oksigen } \\
\text { terlarut } \\
(\mathrm{mg} / \mathrm{L})\end{array}$ \\
\hline \multicolumn{8}{|c|}{ Lokasi 1: Situ Cilalay (tingkat pencemaran rendah) } \\
\hline 1.1 & $\mathrm{~S} 6^{\circ} 29^{\prime} 36,85^{\prime \prime}$ & 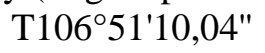 & 149 & 33 & 5 & 4 & 7,5 \\
\hline 1.2 & $\mathrm{~S} 6^{\circ} 29^{\prime} 37,14^{\prime \prime}$ & T106 $51^{\prime} 13,10^{\prime \prime}$ & 152 & 31 & 5 & 6,7 & 7,4 \\
\hline \multirow[t]{2}{*}{1.3} & $\mathrm{~S} 6^{\circ} 29^{\prime} 39,37^{\prime \prime}$ & T10651'11,84" & 158 & 29 & 5 & 6,5 & 6,7 \\
\hline & & Nilai rata-rata & 153 & 31 & 5 & 5,7 & 7,2 \\
\hline \multicolumn{8}{|c|}{ Lokasi 2: Situ Ciriung (tingkat pencemaran tinggi) } \\
\hline 2.1 & $\mathrm{~S} 6^{\circ} 28^{\prime} 03,97^{\prime \prime}$ & $\mathrm{T} 106^{\circ} 51^{\prime} 24,70^{\prime \prime}$ & 140 & 32 & 6 & 5,8 & 6,6 \\
\hline 2.2 & $\mathrm{~S}^{\circ} 28^{\prime} 16,93^{\prime \prime}$ & $\mathrm{T} 106^{\circ} 51^{\prime} 19,01^{\prime \prime}$ & 139 & 32 & 6 & 6,3 & 2,5 \\
\hline \multirow[t]{2}{*}{2.3} & $\mathrm{~S}^{\circ} 28^{\prime} 10,56^{\prime \prime}$ & $\mathrm{T} 106^{\circ} 51^{\prime} 29,56^{\prime \prime}$ & 132 & 33 & 6 & 6,6 & 2,8 \\
\hline & & Nilai rata-rata & 137 & 32,3 & 6 & 6,2 & 3,9 \\
\hline \multicolumn{8}{|c|}{ Lokasi 3: Situ Kabantenan (tingkat pencemaran tinggi) } \\
\hline 3.1 & $\mathrm{~S}^{\circ} 28^{\prime} 52,00^{\prime \prime}$ & $\mathrm{T} 106^{\circ} 50^{\prime} 00,96^{\prime \prime}$ & 127 & 32 & 6 & 6,4 & 5,8 \\
\hline 3.2 & $\mathrm{~S}^{\circ} 28^{\prime} 50,38^{\prime \prime}$ & $\mathrm{T} 106^{\circ} 49^{\prime} 51,56^{\prime \prime}$ & 130 & 32 & 6 & 6,6 & 5,5 \\
\hline \multirow[t]{2}{*}{3.3} & $\mathrm{~S}^{\circ} 28^{\prime} 56,68^{\prime \prime}$ & $\mathrm{T} 106^{\circ} 49^{\prime} 58,87^{\prime \prime}$ & 146 & 33 & 6 & 6,8 & 7,2 \\
\hline & & Nilai rata-rata & 134,3 & 32,3 & 6 & 6,6 & 6,1 \\
\hline \multicolumn{8}{|c|}{ Lokasi 4: Situ Gunung (tingkat pencemaran rendah) } \\
\hline 4.1 & S6 $499^{\prime} 59,26^{\prime \prime}$ & $\mathrm{T} 106^{\circ} 55^{\prime} 27,19^{\prime \prime}$ & 1.020 & 29 & 6 & 6,6 & 8,7 \\
\hline 4.2 & S6 $699 ' 55,47^{\prime \prime}$ & T1065' $17,61 "$ & 1.021 & 26 & 6 & 6,1 & 11,4 \\
\hline \multirow[t]{2}{*}{4.3} & S6 $49 ' 51,72^{\prime \prime}$ & T1065' $16,94 "$ & 1.021 & 26 & 6 & 6,1 & 7,1 \\
\hline & & Nilai rata-rata & $1.020,3$ & 27 & 6 & 6,2 & 9,1 \\
\hline
\end{tabular}

Tabel 4. Nilai uncorrelation Pearson dari hasil CCA antara jumlah spesies dan empat parameter fisikakimia air, tanpa parameter ketinggian. Nilai $\mathrm{p}<0,05$ dianggap berkorelasi antarvariabel

\begin{tabular}{lcccc}
\hline \multicolumn{1}{c}{ Nama spesies } & Suhu $\left({ }^{\circ} \mathrm{C}\right)$ & $\mathrm{pH}$ air & $\mathrm{pH}$ substrat & $\begin{array}{c}\text { Oksigen terlarut } \\
(\mathrm{mg} / \mathrm{L})\end{array}$ \\
\hline Filopaludina javanica & 0,02125 & 0,82784 & 0,45751 & 0,20319 \\
Sermyla riqueti & 0,05394 & 0,58845 & 0,88891 & 0,02697 \\
Wattebledia crosseana & 0,26458 & 0,4791 & 0,77949 & 0,01281 \\
Sulcospira testudinaria & 0,00196 & 0,37972 & 0,98626 & 0,00835 \\
\hline
\end{tabular}



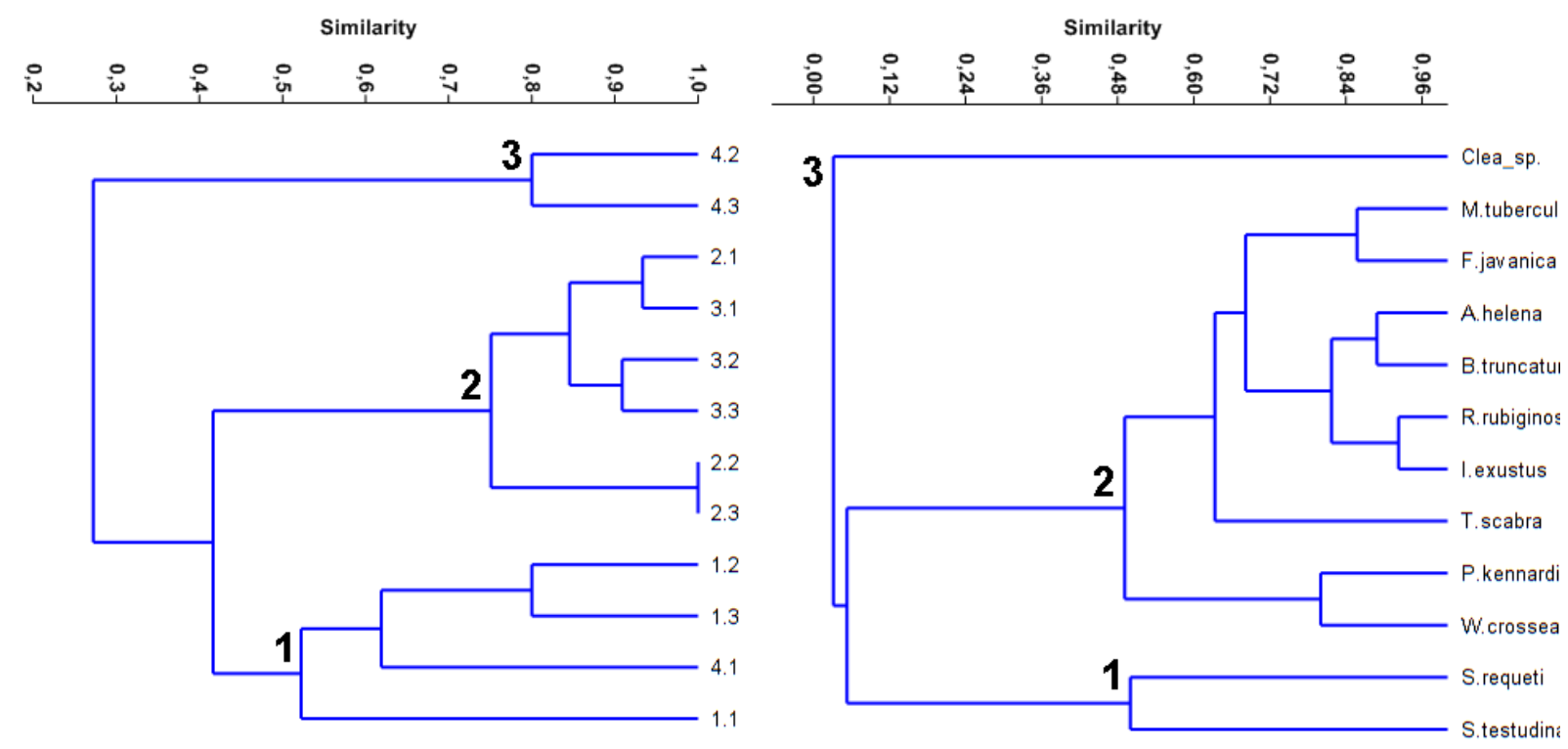

Gambar 3. Kiri: fenogram klaster berdasarkan persamaan komposisi spesies (Bray-Curtis, korelasi kofenetik 0,8646). Kanan: fenogram klaster berdasarkan persamaan pola distribusi spesies (Bray-Curtis, korelasi kofenetik 0,9248)

Di Situ Cilalay dengan tingkat pencemaran rendah, keong air tawar yang ditemukan berjumlah 136 individu yang terdiri dari 3 spesies. Di Situ Ciriung dengan tingkat pencemaran tinggi, ada 297 individu keong air tawar yang ditemukan, yang terdiri dari 9 spesies. Situ Kabantenan dengan tingkat pencemaran tinggi memiliki 451 individu yang terdiri dari 8 spesies, sedangkan Situ Gunung dengan tingkat pencemaran rendah memiliki 39 individu yang terdiri dari 5 spesies.

Analisis klaster dengan membandingkan pola persamaan komposisi spesies dan pola distribusi spesies memperlihatkan ada tiga kelompok utama (Gambar 3). Gambar kiri memperlihatkan semua stasiun di Lokasi 1 (Situ Cilalay) termasuk dalam satu kelompok yang sama dengan Stasiun 4.1 (Situ Gunung), yaitu kelompok 1 yang merupakan lokasi tempat ditemukan spesies Filopaludina javanica. Kelompok 2 (Situ Ciriung dan Situ Kabantenan) merupakan kelompok tempat spesies Melanoides tuberculata ditemukan. Kelompok 3 (stasiun di Situ Gunung) merupakan kelompok tempat spesies Sulcospira testudinaria ditemukan. Kelompok 1 (Sermyla riqueti dan Sulcospira testudinaria) dalam gambar kanan merupakan spesies yang terdapat di Stasiun 4.2. Spesies pertama hanya ditemukan di Stasiun 4.2 saja, sedangkan spesies kedua dapat ditemukan di semua stasiun di Lokasi 4. Kelompok 3 (Clea sp.) merupakan spesies yang hanya terdapat di
Stasiun 1.3, serta sembilan spesies lain dari kelompok 3 memiliki pola distribusi yang lebih luas.

\section{Pembahasan}

Berdasarkan indeks dominansi, semua stasiun dapat dikelompokkan menjadi tiga, yaitu kategori tinggi tempat spesies dominan ditemukan (Stasiun 1.1), kategori sedang (Stasiun 4.3 dan Stasiun 1.2), dan sembilan stasiun lain yang tergolong kategori rendah. Berdasarkan indeks keanekaragaman, stasiun penelitian dapat dikelompokkan menjadi tiga, yaitu kategori rendah (Stasiun 1.1, 1.2), kategori tinggi (Stasiun 2.2, 3.1, 3.3), dan kategori sedang (tujuh stasiun sisanya). Sementara itu, berdasarkan indeks kemerataan, stasiun penelitian dapat dikelompokkan menjadi dua, yaitu kategori sedang untuk Stasiun 2.2, 2.3, 3.1, 3.2 dan kategori tinggi untuk delapan stasiun yang lain.

Stasiun penelitian berada pada ketinggian yang berkisar dari $127 \mathrm{~m}$ dpl (Situ Cilalay) sampai $1.021 \mathrm{~m}$ dpl (Situ Gunung). Hal ini diduga berpengaruh terhadap kondisi parameter fisika-kimia air yang bervariasi. Suhu air berkisar $26-33^{\circ} \mathrm{C}$. Lokasi 4 memiliki suhu paling rendah (rata-rata $27^{\circ} \mathrm{C}$ ), dibandingkan ketiga lokasi yang lain $\left(31-32^{\circ} \mathrm{C}\right)$. Perbedaan suhu ini dikarenakan perbedaan ketinggian situ- 
situ yang diteliti, dengan Lokasi 4 yang berada di atas $1.000 \mathrm{~m}$ dpl. Umumnya semakin tinggi suatu tempat, maka suhunya semakin dingin. Menurut Peraturan Pemerintah No. 82 Tahun 2001, semua situ yang diteliti tergolong dalam rentang Kelas I-III dengan deviasi suhu $3-4^{\circ} \mathrm{C}$.

Kadar oksigen terlarut berkisar 2,5-11,4 $\mathrm{mg} / \mathrm{L}$. Berlawanan dengan suhu, oksigen terlarut di Lokasi 4 justru paling tinggi $(9,1 \mathrm{mg} / \mathrm{L})$ dibandingkan ketiga lokasi yang lain (3,9-7,2 $\mathrm{mg} / \mathrm{L}$ ). Kadar oksigen terlarut yang tinggi di Lokasi 4 diduga karena berada di atas bukit dengan dikelilingi hutan alami serta tingkat pencemaran yang rendah. Menurut Peraturan Pemerintah No. 82 Tahun 2001 berdasarkan parameter oksigen terlarut, hanya Situ Ciriung saja yang tergolong ke dalam Kelas III.

Semua situ dalam penelitian ini memiliki $\mathrm{pH}$ air yang berkisar 5,0-6,0, sedangkan $\mathrm{pH}$ substrat 5,7-6,6. Menurut Peraturan Pemerintah No. 82 Tahun 2001, hanya Situ Cilalay dan Situ Ciriung saja yang tergolong ke dalam Kelas IV karena nilai $\mathrm{pH}$ substratnya paling rendah $(5,7)$. Hal ini kemungkinan karena statusnya sebagai danau buatan yang masih dalam proses menuju kesetimbangan ekologi. (Puspita, 2017).

Secara keseluruhan, ada dua parameter fisika-kimia air yang terlihat berbeda antar lokasi, yaitu suhu air dan kadar oksigen terlarut. Untuk Lokasi 1-3 dengan ketinggian yang relatif sama, kadar oksigen terlarut tertinggi ada di Lokasi 1. Hal ini diduga berkaitan dengan status pencemarannya yang rendah. Ekosistem perairan yang tercemar tinggi (Situ Ciriung dan Situ Kabantenan) memerlukan banyak oksigen untuk proses perombakan bahan organik yang mengendap, sehingga sisa kandungan oksigen terlarutnya menjadi rendah (Rahayu et al., 2018).

Ketinggian tempat di Lokasi 1-3 berkisar 120-160 m dpl. Lokasi 4 (Situ Gunung) dipilih sebagai pembanding karena memiliki ketinggian di atas $1.000 \mathrm{~m}$ dpl yang sangat berbeda dari ketiga lokasi yang lain. Oleh karena itu, Tabel 4 tidak mencantumkan parameter ketinggian karena sudah jelas berbeda. Beberapa faktor abiotik turut memengaruhi kelimpahan, jumlah spesies keong, dan kemerataan tiap spesies di suatu habitat. Hasil analisis CCA (Tabel 4) menunjukkan bahwa hanya ada empat spesies yang memiliki keterkaitan yang kuat dengan parameter fisika-kimia air. Filopaludina javanica hanya dijumpai di stasiun dengan suhu minimum $29^{\circ} \mathrm{C}$. Keong ini tidak dijumpai di Stasiun 4.2 dan 4.3 dengan suhu $26^{\circ} \mathrm{C}$. Hal ini didukung oleh hasil penelitian Rijaluddin et al. (2017) yang menjumpai spesies ini hanya di perairan dengan suhu $29^{\circ} \mathrm{C}$ atau lebih.

Sermyla riqueti hanya dijumpai di Stasiun 4.2 saja yang memiliki kandungan oksigen tertinggi $(11,4 \mathrm{mg} / \mathrm{L})$. Wattebledia crosseana hanya dijumpai di Stasiun 2.2 dan 2.3 saja yang memiliki kandungan oksigen terendah $(2,5-2,8$ $\mathrm{mg} / \mathrm{L}$ ). Hasil penelitian Priawandiputra et al., (2017) menunjukkan spesies Sermyla riqueti hidup di perairan dengan kandungan oksigen 5$6 \mathrm{mg} / \mathrm{L}$ dan Wattebledia crosseana hidup di perairan dengan kandungan oksigen $6 \mathrm{mg} / \mathrm{L}$. Hasil penelitian kami menambah kisaran toleransi kedua spesies tersebut terhadap kandungan oksigen terlarut perairan.

Sulcospira testudinaria dijumpai di semua stasiun di Lokasi 4 saja dengan kisaran suhu $26-29^{\circ} \mathrm{C}$ dan kandungan oksigen terlarut 7,1-11,4 mg/L. Sebenarnya, spesies ini mungkin dapat dijumpai di Stasiun 1.3 dengan suhu $29^{\circ} \mathrm{C}$, namun kemungkinan karena kandungan oksigen terlarutnya rendah $(<7,1 \mathrm{mg} / \mathrm{L})$, maka keong ini tidak dijumpai di sini.

Beberapa penelitian serupa telah dilakukan di situ-situ sekitar Jabotabek. Marwoto \& Isnaningsih (2014) melaporkan keberadaan sembilan famili dan 13 spesies keong air tawar dari 36 situ di sepanjang DAS Ciliwung dan Cisadane. Sebanyak enam famili dan 10 spesies keong air tawar dilaporkan dari sekitar kampus ITB Sumedang (Oktarina \& Syamsudin, 2015). Sebanyak lima famili dan 11 spesies keong air tawar dilaporkan dari tiga situ di Ciputat Timur, Provinsi Banten (Rijaluddin et al., 2017). Jumlah yang sama juga dilaporkan dari Situ Gintung, Provinsi Banten (Assuyuti et al., 2017). Priawandiputra et al., (2017) melaporkan sebanyak tujuh famili dan 14 spesies keong air tawar dari tiga situ di Dramaga, Kabupaten Bogor. Semua studi di atas mencantumkan spesies pendatang Keong Mas (Pomacea canaliculata: Ampullariidae) dalam daftar spesiesnya. Berbeda dari kelima penelitian terdahulu, penelitian ini tidak mencantumkan spesies pendatang tersebut dalam daftar spesies meskipun sebenarnya spesies tersebut dijumpai di semua lokasi. Kami juga tidak menghitung jumlah populasinya. Mungkin studi lanjutan khusus diperlukan bila populasi dan dampaknya bagi ekosistem situ ingin dipelajari.

Situ Kabantenan pernah diteliti sebelumnya oleh Marwoto \& Isnaningsih (2014). Mereka melaporkan sebanyak lima 
famili dan lima spesies di lokasi tersebut, sedangkan penelitian ini mencatat sebanyak enam famili dan delapan spesies. Secara keseluruhan, terdapat empat spesies yang sama pada kedua penelitian tersebut. Satu spesies lain yang dilaporkan oleh Marwoto dan Isnaningsih (2014) dari Situ Kabantenan adalah Pomacea canaliculata. Bila dibandingkan dengan empat penelitian lain (Assuyuti et al., 2017; Priawandiputra et al., 2017; Rijaluddin et al., 2017; Oktarina \& Syamsudin, 2015), penelitian ini menunjukkan kemiripan yang paling dekat dengan penelitian Marwoto \& Isnaningsih (2014). Selain itu, penelitian ini menemukan dua spesies yang belum pernah dilaporkan oleh kelima penelitian terdahulu, yaitu Clea sp. dan Polypylis kennardi. Clea sp. masih satu famili dengan Anentome helena, namun secara morfologi Clea sp. tidak memiliki axial ribs. Van Benthem Jutting (1956) pernah melaporkan keberadaan Anentome helena dan Polypylis kennardi di Jawa, namun tidak melaporkan Clea $\mathrm{sp}$.

Filopaludina javanica mendominasi populasi dengan jumlah 420 individu $(44,8 \%$, kepadatan 35 individu $/ \mathrm{m}^{2}$ ) dan tersebar di 10 stasiun. Hal yang sama juga dilaporkan oleh Priawandiputra et al., (2017). Spesies ini merupakan pemakan deposit bahan organik yang mengendap di substrat dasar perairan (Sari et al., 2016). Kemampuan adaptasinya tinggi, sehingga keong ini dapat hidup di danau, rawa, kolam, saluran irigasi, dan sungai, biasanya hidup menempel di batu-batuan atau bersembunyi di dasar berlumpur (Djajasasmita, 1999). Sementara itu, Melanoides tuberculata merupakan spesies yang paling tersebar luas yang dijumpai di 11 dari 12 stasiun yang diteliti. Hal yang sama juga dilaporkan oleh Marwoto \& Isnaningsih (2014). Spesies ini juga tahan terhadap pencemaran dari limbah rumah tangga (Surbakti, 2011). Penelitian ini membuktikan bahwa Melanoides tuberculata mampu bertahan di situ yang tercemar (Lokasi 1 dan 2) dan hanya kalah jumlahnya dari Filopaludina javanica (159 individu dibanding 420 individu).

Di sisi lain, Filopaludina javanica menunjukkan penyebaran di hampir seluruh stasiun (kecuali Stasiun 4.2 dan 4.3). Marwoto \& Isnaningsih (2014) menemukan spesies ini di 24 situ dari 36 situ yang diteliti dan merupakan spesies dengan persebaran terluas. Walaupun spesies keong ini terbilang kosmopolit, yang dapat ditemukan di semua lempeng benua kecuali Amerika Selatan (van Benthem Jutting,
1956), namun berdasarkan justifikasi analisis Uncorrelation, parameter suhu berkorelasi dengan spesies ini (Tabel 4). Nilai korelasi mengindikasikan bahwa spesies keong ini berlimpah pada saat berada di lokasi yang rendah dan bersuhu hangat. Untuk sementara, belum ada penjelasan antara ketinggian dan jumlah individu pada spesies keong air tawar, namun pola yang sama terlihat pada kerabat mereka keong darat. Menurut Albano et al. (2014) dan Wronski et al. (2014), hal itu dimungkinkan oleh ketersediaan nutrisi dan transisi habitat.

Sampai saat ini, belum ada penjelasan tentang hubungan suhu air dengan jumlah spesies keong, namun spesies keong ini memang memiliki kemampuan adaptasi tinggi di berbagai tipe lingkungan dan habitat (Priawandiputra et al., 2017; Ng et al., 2016; Marwoto \& Isnaningsih, 2014; Sharma et al., 2013), sehingga spesies keong ini mungkin dapat juga bertahan di habitat bersuhu rendah.

Tingkat pencemaran perairan dapat memengaruhi jumlah jenis dan individu. Di Situ Cilalay dan Situ Gunung dengan tingkat pencemaran rendah 6 spesies dan 175 individu keong ditemukan. Sebaliknya, di Situ Ciriung dan Situ Kabantenan dengan tingkat pencemaran tinggi 9 spesies dan 761 individu ditemukan. Di situ yang tercemar tinggi (Ciriung dan Kabantenan), umumnya kandungan oksigen terlarut berkorelasi positif dengan jumlah individu. Hal itu bisa terlihat pada enam spesies (Filopaludina javanica, Radix rubiginosa, Thiara scabra, Indoplanorbis exustus, Polypylis kennardi, dan Bithynia truncatum) yang ditemukan di kedua lokasi yang tercemar tinggi. Dua spesies lain (Melanoides tuberculata dan Anentome helena) memiliki pola sebaliknya. Jumlah individu kedua spesies tersebut justru lebih banyak di lokasi dengan kandungan oksigen terlarut yang rendah. Satu spesies, Wattebledia crosseana, justru hanya ditemukan di situ yang kandungan oksigen terlarutnya paling rendah (Situ Kabantenan: 3,9 mg/L). Spesies ini ditemukan juga di perairan dengan kandungan oksigen terlarut $6 \mathrm{mg} / \mathrm{L}$ (Priawandiputra et al., 2017). Hasil penelitian ini menambahkan informasi kebutuhan kandungan oksigen terlarut untuk spesies ini yang berkisar 3,9-6 mg/L.

Keberadaan permukiman yang berdampak pada pencemaran air di situ ternyata tidak selalu memiliki efek negatif, paling tidak bagi komunitas keong air tawar. Data kami menunjukkan bahwa situ yang tidak tercemar 
(Lokasi 1 dan 4) memiliki jumlah spesies dan kelimpahan individu lebih rendah (enam spesies, 175 individu) bila dibandingkan dengan dua lokasi tercemar (Lokasi 2 dan 3, sembilan spesies dan 761 individu). Hal yang sama juga dilaporkan oleh Tchakonte et al. (2014) dan Savic et al. (2016). Suhu air yang relatif lebih tinggi di dua lokasi tercemar $\left(32,3^{\circ} \mathrm{C}\right)$ turut mempercepat dekomposisi unsur organik pada polutan yang akan menjadi sumber makanan bagi keong (Bath et al., 1999). Unsur organik yang berlimpah menjadi penyebab jumlah individu keong yang banyak di sana. Hanya ada dua spesies keong yang mampu bertahan terhadap pencemaran, yaitu Filopaludina javanica dan Melanoides tuberculata. Hal ini ditandai dengan jumlah individu yang lebih banyak di situ yang tercemar. Jumlah kedua spesies tersebut adalah 421 individu (55,3\%) dari populasi total 761 individu. Marwoto \& Isnaningsih (2014) menemukan spesies Filopaludina javanica di 24 situ serta Melanoides tuberculata di 22 situ dari 36 situ yang diteliti. Meskipun demikian, ada dua faktor yang diduga membatasi keberadaan spesies Filopaludina javanica, yaitu $\mathrm{pH}$ substrat dan kadar oksigen terlarut. Populasi keong di Lokasi 2 (pH substrat 6,2; oksigen terlarut 3,9 mg/L) terhitung 114 individu, sedangkan populasi di Lokasi 3 (pH substrat 6,6; oksigen terlarut 6,1 $\mathrm{mg} / \mathrm{L}$ ) terhitung 209 individu. Hal tersebut menunjukkan bahwa pencemaran air situ akan memicu proses seleksi alam, yaitu hanya spesies tertentu saja yang dapat bertahan hidup dengan kondisi minim oksigen dalam jangka waktu yang panjang. Surbakti (2011) menemukan spesies Melanoides tuberculata di perairan yang tercemar oleh limbah rumah tangga, sementara kerabatnya Thiara scabra ditemukan di perairan bersih yang jauh dari permukiman.

Kondisi $\mathrm{pH}$ substrat 6,2-6,6 termasuk asam. Kondisi asam kurang cocok bagi keong karena akan menghambat sintesis kalsium karbonat $\left(\mathrm{CaCO}_{3}\right)$ dalam pembentukan cangkangnya, sehingga lambat laun akan terjadi korosi pada cangkangnya. Hal ini bisa dikompensasi oleh keong air, namun akan memerlukan asupan energi yang jauh lebih banyak dibanding pada keadaan normal (Lefcort et al., 2015). Lebih jauh, Spyra (2017) melaporkan pada kondisi perairan asam akan dijumpai lebih sedikit jumlah individu maupun spesies keong air dibandingkan kondisi netral $(\mathrm{pH} 7)$.
Dalam perairan yang tercemar, oksigen dibutuhkan untuk mengurai partikel polutan, sehingga kadar oksigen terlarut dalam air menjadi turun. Berg \& Ockelmann (1959) melakukan pengukuran aktivitas respirasi 10 spesies keong air tawar. Mereka melaporkan hanya ada satu spesies yang mampu mengatur laju respirasi tetap stabil dalam kondisi oksigen yang turun. Respirasi pada sembilan spesies lain ikut turun sehingga laju fungsi fisiologisnya juga menurun. Stenomelania torulosa (Thiaridae) mampu menjaga respirasinya pada kondisi perairan tercemar insektisida (Bharathi \& Rao, 1989). Hal yang sama juga dilaporkan pada Viviparus contectoides (Viviparidae) (Studier \& Pace, 1978). Kedua spesies tersebut masih berkerabat dekat dengan Melanoides tuberculata (Thiaridae) dan Filopaludina javanica (Viviparidae) yang ditemukan dalam penelitian ini. Kemampuan kedua spesies ini kemungkinan setara dengan kerabatnya, sehingga mereka berhasil bertahan dalam perairan tercemar. Meskipun demikian, mereka akan mengalami penurunan populasi, seperti yang ditunjukkan oleh Melanoides tuberculata di Stasiun 2.2, 2.3, 3.1, 3.2, dan Indoplanorbis exustus di Stasiun 3.1 dan 3.2. Spesies yang tak mampu bertahan akan punah secara lokal, seperti Thiara scabra di Stasiun 2.2 dan 2.3. Hal tersebut tentunya tidak diharapkan.

\section{Kesimpulan}

Komposisi spesies keong air tawar di situ di dataran rendah Kabupaten Bogor relatif lebih banyak dibandingkan dengan situ di dataran tinggi Kabupaten Sukabumi. Dua spesies yang dominan yaitu Filopaludina javanica dan Melanoides tuberculata mampu bertahan hidup dalam perairan yang tercemar, sehingga populasinya banyak dan distribusinya luas. Kandungan oksigen terlarut dan $\mathrm{pH}$ substrat merupakan faktor yang paling menentukan keragaman dan populasi keong air tawar.

\section{Ucapan Terima Kasih}

Penulis mengucapkan terima kasih kepada Departemen Biologi, FMIPA-IPB yang telah memfasilitasi penelitian ini dan juga kepada kepala Laboratorium Moluska Museum Zoologi Bogor (R M Marwoto dan teknisi (Alfiah dan R Prihandini) atas bantuannya selama proses 
identifikasi spesimen. Kegiatan penelitian ini merupakan bagian dari mata kuliah Eksplorasi Habitat yang dibiayai oleh Departemen Biologi, FMIPA-IPB.

\section{Referensi}

Albano PG, D'occhio P, Strazzari G, Succetti F, Sabelli B. 2014. Land-mollusc forest communities along an altitudinal transect in Northern Italy. Journal of Molluscan Studies 80: 55-61

Assuyuti YM, Rijaluddin AF, Ramadhan F, Zikrillah RB, Kusuma DC. 2017. Struktur komunitas dan distribusi temporal gastropoda di danau Situ Gintung, Tangerang Selatan, Banten. Scripta Biologica 4(3): 139-146

Bath KS, Kaur H, Dhillon SS. 1999. Correlation of Molluscs with physico-chemical factors at Harike Reservoir (Punjab). Indian Journal of Environmental Science 3: 159-163

Berg KAJ, Ockelmann KW. 1959. The respiration of freshwater snails. Journal of Experimental Biology 36: 690-708

Bharathi C, Rao DGVP. 1989. Toxicity to and oxygen consumption of the freshwater snail Thiara (Stenomelania) torulosa (Bruguiere) in relation to organophosphorus insecticide exposure. Bulletin Environmental Contamination and Toxicology 42:773-777

Djajasasmita M. 1999. Keong dan kerang sawah. Puslitbang Biologi-LIPI, Bogor

Hammer $\varnothing$, Harper DAT, Ryan PD. 2001 PAST Paleontological Statistics Software Package for education and data analysis. Paleontologia Eletronica 4(1): 1-9

Hadiaty RK. 2011. Diversitas dan kehilangan jenis ikan di danau-danau aliran Sungai Cisadane. Jurnal Iktiologi Indonesia 11(2):143-157

Lefcort H, Cleary DA, Marble AM, Phillips MV, Stoddard TJ, Tuthill LM, Winslow JR. 2015. Snails from heavy-metal polluted environments have reduced sensitivity to carbon dioxide-induced acidity. Springerplus 4(267): 1-9

Magurran AE. 2004. Measuring Biological Diversity. Blackwell Science LTD, Malden

Marwoto RM, Isnaningsih NR. 2014. Tinjauan keanekaragaman moluska air tawar di beberapa situ di DAS Ciliwung-Cisadane. Berita Biologi 13(2): 181-189

Ng TH, Tan SK, Wong WH, Meier R, Chan SY, Tan HH, Yeo CJ. 2016. Molluscs for sale: assessment of freshwater gastropods and bivalves in the ornamental pet trade. PLoS ONE 11(8) e0161130 doi:10.1371/journal.pone.0161130.

Nugroho A. 2006. Bioindikator Kualitas Air. Universitas Trisakti, Jakarta

Oktarina A, Syamsudin TS. 2015. Keanekaragaman dan distribusi makrozoobentos di perairan lotik dan lentik Kawasan Kampus Institut Teknologi Bandung, Jatinangor Sumedang, Jawa Barat. Prosiding Seminar Nasional Masyarakat Biodiversitas Indonesia 1(2): 227-235

Peraturan Pemerintah Republik Indonesia No. 82 Tahun 2001 tentang Pengelolaan Kualitas Air dan Pengendalian Pencemaran Air

Priawandiputra W, Nasution DJ and Prawasti TS. 2017. Comparison of freshwater mollusc assemblages between dry and rainy season in Situ Gede System, Bogor, Indonesia. IOP Conference Series:Earth and Enviromental Science 58012007

Puspita ID. 2017. Kajian Konsep Pengembangan Waterfront Berbasis Desain Ekologis di Cibinong Raya. Tesis. Sekolah Pasca Sarjana Institut Pertanian Bogor. Bogor

Rahayu Y, Juwana I, Marganingrum D. 2018. Kajian perhitungan beban pencemaran air sungai di Daerah Aliran Sungai (DAS) Cikapundung dari sektor domestik. Jurnal Rekayasa Hijau 1(2): 63-71

Rijaluddin AF, Wijayanti F, Haryadi J. 2017. Struktur komunitas makrozoobentos di Situ Gintung, Situ Bungur dan Situ Kuru, Ciputat Timur. Jurnal Teknologi Lingkungan 18(2): 139-147

Sari WP, Bahtiar, Emiyarti. 2016. Studi preferensi habitat siput tutut (Bellamya javanica) di Desa Amonggedo Kabupaten Konawe. Jurnal Manajemen Sumber Daya Perairan 1(2): 213-224

Savic A, Randelovic V, Dordevic M, Pešic V. 2016. Assemblages of freshwater snails (Mollusca: Gastropoda) from the Nišava River, Serbia: ecological factors defining their structure and spatial distribution. Acta Zoologica Bulgarica 68(2): 235-242

Sharma KK, Bangotra K, Saini M. 2013. Diversity and distribution of Mollusca in relation to the physico-chemical profile of Gho-Manhasan stream, Jammu. International Journal of Biodiversity and Conservation 5(4): 240-249

Spyra A. 2017. Acidic, neutral and alkaline forest ponds as a landscape element affecting 
the biodiversity of freshwater snails. The Science of Nature 104(73): 1-12

Studier EH, Pace GL. 1978. Oxygen consumption in the prosobranch snail Viviparus contectoides (Mollusca: Gastropoda)-IV. Effects of dissolved oxygen level, starvation, density, symbiotic algae, substrate composition and osmotic pressure. Comparative Biochemistry and Physiology Part A: Physiology 59(2): 199 203

Surbakti SBR. 2011. Biologi dan ekologi Thiaridae (Moluska: Gastropoda) di Danau Sentani Papua. Jurnal Biologi Papua 3(2): 59-66

Suryadiputra INN. 2003. Penelitian Situ-situ di Jabodetabek. Dalam Manajemen Bioregional Jabodetabek : Tantangan dan Harapan, Hal. 205-228. Ubaidillah R, Maryanto I, Amir M, Noerdjito M, Prasetyo EB, Polosakan R. Bogor: Pusat Penelitian Biologi - LIPI
Tchakonte S, Ajeagah GA, Diomandé D, Camara AI, Ngassam P. 2014. Diversity, dynamic and ecology of freshwater snails related to environmental factors in urban and suburban streams in Douala-Cameroon (Central Africa). Aquatic Ecology 48(4): 379-395

van Benthem Jutting WSS. 1956. Systematic studies on the non-marine mollusca of the Indo-Australian Archipelago: V. Critical revision of the Javanese freshwater gastropod. Treubia 23(2): 259-477

Wronski T, Gilbert K, Long E, Micha' B, Quinn R, Hausdorf B. 2014. Species richness and meta-community structure of land snails along an altitudinal gradient on Bioko Island, Equatorial Guinea. Journal of Molluscan Studies 80: 161-168 